\title{
Effect of landfill leachate on germination of lettuce seeds (Lactuca sativa L.)
}

\author{
Heider Alves Franco ${ }^{1}$, Monica Regina da Costa Marques², Clarisse Ferreira Braga ${ }^{3}$, \\ Allana de Souza Izidorio ${ }^{4}$, Sérgio Thode Filho ${ }^{5}$
}

\begin{abstract}
1Professor at the Federal Institute of Education, Science and Technology of Rio de Janeiro - IFRJ, Campus Pinheiral, RJ, Multidisciplinary Laboratory of Agro-Environmental Technology - LAMTAA. heider.franco@ifrj.edu.br

${ }^{2}$ Professor at the State University of Rio de Janeiro - UERJ, Environmental Technology Laboratory - LABTAM

${ }^{3}$ Student of the Technical Course in Environment - IFRJ, Campus Pinheiral, RJ, Multidisciplinary Laboratory of AgroEnvironmental Technology - LAMTAA

${ }^{4}$ Laboratory assistant at the Federal Institute of Education, Science and Technology of Rio de Janeiro - IFRJ, Campus Pinheiral, RJ

${ }^{5}$ Professor at the Federal Institute of Education, Science and Technology of Rio de Janeiro - IFRJ - IFRJ, Campus Duque de Caxias, RJ, Multidisciplinary Waste Management Laboratory - LMGR
\end{abstract}

\begin{abstract}
The constant changes in the relation of consumption increased solid waste generation. Associated to this is the formation of leachate that accumulate in landfills, presenting as an effluent with high polluting potential. The physico-chemical analyzes allow to identify and quantify the elements present. However, it is also important to carry out ecotoxicological tests to understand the relationship with the environment. Germination assays with lettuce (Lactuca sativa L.) submitted to different dosages of landfill leachate $(3.125 \%, 6.25 \%, 12.5 \%, 25 \%, 50 \%$ and $100 \%)$ were proposed in two substrates: filter paper and soil. The objective of this work was evaluate the direct and indirect impact of the leachate on the germination of lettuce seeds, through determination of the LC50 and the values of NOEC and LOEC. In both trials it was not possible to determine the LC50 from the doses tested. The filter paper test showed to be more restrictive asthe determination of LOEC-0 occurred with the treatment of $3.125 \%$. For the soil test the results are more flexible, the LOEC value is obtained with the $25 \%$ dose. The physiological behavior of the lettuce showed different relations from the introduction of the pollutant, but mainly in relation to the substrate used for germination.
\end{abstract}

Keywords: Landifill leachate. Germination. Ecotoxicity. Environmental impact.

\section{Introduction}

The consumer relations stimulated over the years culminated with the potential increase of waste production, specially urban solid waste (USW). The management and destination of these, commonly called garbage, has become a great humanity problem. According to CARVALHO et 
al. (2006), the volume generated is about 259,547 tons/day in Brazilian municipalities, totaling 1.26 $\mathrm{kg}$ of waste per capita per day (IBGE, 2008).

The USW are characterized by a complex mixture of materials of diverse nature, consisting of: organic matter; materials (paper, cardboard, wood branches) and inert materials (plastics, glass, metal, etc.) (Carvalho et al., 2006).

This feature makes the USW decomposition process extremely complex due to the formation of leachate. Special attention should be given to the leachate generated in landfills, as it is a potentially polluting liquid that can attack nearby natural resources if it is not treated and discarded in a careful and controlled way (SALEM et al. 2008).

The chemical characterization of the landfill leachate discriminate the substances present in the landfill. However it is not possible to infer its direct impact on the ecosystem. Thus, ecotoxicity tests are carried out on different test organisms. The germination and root development test of plants is commonly used to evaluate the impact of a potential pollutant on the flora (COSTA et al., 2008; KALCIKOVA et al., 2011). Since, as seeds tolerate certain levels of stress and because their vital functions are strictly correlated with the environment, they can indicate the effect of environmental factors (BASSANI, 2001; CARITÁ; MARIN-MORALES, 2008).

Germination tests are performed to determine the potential effect of a pollutant. To determine the concentration / lethal dose capable of causing death or inhibition in $50 \%$ of test organisms (LC50), it is also possible to determine the lowest concentration in which the pollutant effect is observed (LOEC), as well as the higher concentration in which no deleterious effect is observed (NOEC) (ADAMS et al., 2002; RONCO et al., 2004).

The Organization for Economic Cooperation and Development (OECD), publish a list of species for this type of trial, amoone of them being lettuce (Lactuca sativa L.) (OECD, 2003). Seeds of the species Lactuca sativa constitute a good toxicological model for this type of laboratory test, since this plant has a relative vegetal sensitivity in relation to salts (BARASSI et al., 2006).

The objective of this study was to determine the impact potential of the landfill leachate on germination by determination of the LC50 and LOEC and NOEC from lettuce (Lactuca sativa L.) root length on two substrates, filter paper and soil.

\section{Material and methods}

\subsection{Materials}

The tests took place in the Multidisciplinary Laboratory for Agro-environmental Technology of the Pinheiral Campus of the Federal Institute of Rio de Janeiro, located in the municipality of Pinheiral, Rio de Janeiro state.

The landfill leachate used in the study was provided by the company Haztec Tecnologia e Planejamento Ambiental S.A., which manages the Waste Treatment Center (WTC) located in the city of Barra Mansa, with geographic coordinates $22^{\circ} 35^{\prime} 11.52^{\prime \prime} \mathrm{S}$ and $44^{\circ} 12^{\prime} 54.31^{\prime \prime} \mathrm{W}$.

The planning, compilation and maintenance of the leachate were performed according to NBR 9897 (ABNT, 1987). The leachate was stored in a plastic container with 50 liter capacity and 25\% of its contents were renewed monthly to avoid losing its properties.

We used seeds of lettuce (Lactuca sativa L.) cv. Baba, from the company Isla seeds, whose germination potential was around $95 \%$. 
Petri dish (9.5 cm diameter) and substrate qualitative filter paper ( $1 \mu \mathrm{m}$ porosity) were used for direct impact testing. For the indirect impact test, the substrate used was a Planosol Hapless $\mathrm{Tb}$ Eutrophic of sandy texture.

The environmental conditions for both assays were: temperature $\left(25 \pm 2{ }^{\circ} \mathrm{C}\right)$ (BRASIL, 2009); photoperiod (12 hours light / 12 hours dark) and total run time of 120 hours (LINDER et al., 1989). These conditions were obtained with the use of a Thelga TF34 BOD chamber, where the container dishes were prepared.

\subsection{Methods}

\subsubsection{Physical and chemical characteristics of landfill leachate.}

The physicochemical characterization was performed according to the method of the American Public Health Association (APHA, 2005). The following parameters were characterized: electrical conductivity (EC), $\mathrm{pH}$ and total dissolved solids (TDS), through direct reading of a waterproof multiparameter PCS Testr 35; and chemical oxygen demand (COD) using the closed reflux colorimetric method of digestion of the samples with a Tecnal TE-021 dry block digester, followed by reading the samples in a Hach DR 5000 spectrophotometer.

The determination of cations and anions was performed by ion chromatography. Samples of landfill leachate were diluted 1000 times and then filtered with syringes coupled to fiberglass filters with $0.22 \mu \mathrm{m}$ pore size to avoid clogging. The filtered material was placed in vials of a Dionex ICs 3000 ion chromatography system. The apparatus was equipped with an IonPac CS16 analytical column $(3.0 \times 250 \mathrm{~mm})$ preceded by two pre-columns. The cation suppressor used was 300 CSRS $(2.0 \mathrm{~mm})$. The equipment also has an IonPac AS 23 analytical column $(2.0 \times 250 \mathrm{~mm})$ preceded by a guard column and an anion suppressor (SRS $2 \mathrm{~mm}$ ). In the mobile phase testing, the cations used for detection were methyl sulfonic acid (MSA) injected into the column with a concentration of $32 \mathrm{mmol} \mathrm{L}^{-1}$. For anions, we used solutions of carbonate/sodium bicarbonate at concentrations of $4.5 \mathrm{mmol} \mathrm{L}^{-1}$ and $0.8 \mathrm{mmol} \mathrm{L}^{-1}$.

For determination of the metal concentrations (Al, Cd, Cr, $\mathrm{Cu}, \mathrm{Fe}, \mathrm{Mn}, \mathrm{Ni}, \mathrm{Pb}$ and $\mathrm{Zn}$ ), samples were digested according to the USEPA procedure (1998): $20.0 \mathrm{~mL}$ of sample and $10.0 \mathrm{~mL}$ of nitric acid $\left(\mathrm{HNO}_{3}\right) \mathrm{PA}$ were placed in a Teflon bottle that was closed and heated in a microwave oven (Milestone Start E) with a power of $600 \mathrm{~W}$ for $20 \mathrm{~min}$ (heating to $170{ }^{\circ} \mathrm{C}$ for 10 minutes and maintained at $170{ }^{\circ} \mathrm{C}$ for 10 minutes). The product obtained was passed through filter paper and swelled in $100 \mathrm{~mL}$ flat-bottom volumetric flasks. Samples were measured in duplicate with a Varian 240 ASA flame atomic absorption spectrometer. The operating conditions used in the FAAS were the following: exposure time of 5 minutes, air-acetylene flame; airflow of $10.0 \mathrm{~L} \mathrm{~min}^{-}$ 1 , and acetylene flow of $2.0 \mathrm{~L} \mathrm{~min}^{-1}$.

\subsubsection{Effect on germination and development of Lettuce (Lactuca sativa L.) - direct impact.}

The experimental dynamics followed a completely randomized design developed in two groups: test and control. For the test group, six treatments were applied with increasing doses in a ratio of 50\% of landfill leachate, as follows (ARAGÃO et al., 2008 ALMEIDA et al., 2011.): T1 = $3.125 \%$ leachate $+96.875 \%$ deionized water; $\mathrm{T} 2=6.25 \%$ leachate $+93.75 \%$ deionized water; $\mathrm{T} 3=$ $12.5 \%$ leachate $+87.5 \%$ deionized water; $\mathrm{T} 4=25 \%$ leachate $+75 \%$ deionized water; $\mathrm{T} 5=50 \%$ 
leachate $+50 \%$ deionized water; $\mathrm{T} 6=100 \%$ leachate; and control $(\mathrm{TC})=100 \%$ deionized water. All treatments were performed in triplicate.

In the study, 20 seeds of lettuce were divided in Petri dishes $(9.5 \mathrm{~cm}$ in diameter) with qualitative filter paper substrate (porosity $14 \mu \mathrm{m}$ ) and moistened with $4.0 \mathrm{~mL}$ of the sample solutions. To ensure moisture throughout the test, the Petri dishes were wrapped with transparent parafilm and placed in a germination chamber.

\subsubsection{Effect on germination and development of Lettuce (Lactuca sativa L.) - indirect impact.}

For this assay the methodology of LOPES et al (2010) was adapted, $50 \mathrm{~mL}$ plastic containers were filled with $50 \mathrm{~g}$ of sandy soil moistened with $13.5 \mathrm{~mL}$ of solution (landfill leachate + deionized water), according to the treatments applied in the direct impact test. Afterwards, ten (10) lettuce seeds were distributed at equal distances on the soil. Soon after sowing, the plastic containers were covered with parafilm (to minimize possible losses of humidity and incubated in a germination chamber, BOD type.

The soil used in the test was physico-chemically characterized according to the method recommended by the Brazilian Agricultural Research Corporation - EMBRAPA (1997) (Table 2).

\subsection{Evaluation and Statistical Analysis.}

At the end of the experimental period the following parameters were evaluated: number of seeds germinated and not germinated, and length of roots (USEPA, 1996; OECD, 2003). The root length was measured with a digital caliper.

Seeds showing a radicle protrusion were germinated (SOBRERO and RONCO, 2004). Tests were considered valid for germination in the control (deionized water) when germination rate was greater than $80 \%$ (BRASIL, 2009).

For the determination of lethal effects in both tests, the LC50 was identified from comparison of the mean germination and/or graphical analysis.

The sub-lethal effects were determined by the no observed effect concentration (NOEC), which corresponds to the highest concentration/dose of toxicant that causes no statistically significant deleterious effect on the organisms during the exposure time under the test conditions; also,the lowest observed effect concentration (LOEC), which is the lowest concentration/dose of toxicant that causes statistically significant deleterious effect on the organisms during the exposure time and test conditions (RONCO et al., 2004). NOEC and LOEC were determined by comparison between the average length of the roots.

After physical examination and obtaining the means values of variables, these were submitted to the Lilliefors test of normality and Cochran-Bartlett test to determine homogeneity. The ScottKnott test was used to analyze the significance between treatments at $5 \%$ probability. To determine the correlation between the parameters and the concentration of pollutant (landfill leachate), we used the Pearson correlation coefficient $(r)$ and the $t$-test for significance at $p<0.05$ (ACHEN, 1977; ALDRICH, 1995).

The analyzes were carried out with Assistat 7.7 (SILVA \& AZEVEDO, 2016), and graphs plotted using the Microsoft Excel 2013. 


\section{Results and discussion}

According to the physical-chemical parameters presented in Table 1 it is possible to classify landfill leachate as a young leachate (KURNIAWAN et al., 2010). It is also observed that when the physical-chemical parameters of the leachate are compared with the effluent quality standard for release CONAMA 430/2011, this crude leachate does not have characteristics that allow its arrangement in the receiving body, defining it as a potential pollutant. Evaluating the physicalchemical characteristics of the raw landfill leachate (Table 1), it can be noted that the parameters salinity and sodium are above the reference values.

Table 1. Physico-chemical characterization of Barra Mansa-RJ's CTR landfill leachate.

\begin{tabular}{|c|c|c|c|}
\hline \multirow{2}{*}{ Evaluated parameters } & \multirow{2}{*}{ Unit } & \multirow{2}{*}{ Observed values } & \multirow{2}{*}{$\begin{array}{c}\text { CONAMA } 430 \\
\text { Effluent } \\
\text { discharge }^{1}\end{array}$} \\
\hline & & & \\
\hline $\mathrm{pH}$ (water) & ------- & 9.0 & $5.0-9.0$ \\
\hline Conductivity & $\mathrm{d} S \mathrm{~m}^{-1}$ & 33.3 & N.D. \\
\hline COD & $\mathrm{mg} \mathrm{L}^{-1}$ & 5592 & 120 \\
\hline TDS & $\mathrm{mg} \mathrm{L}^{-1}$ & 23600 & N.D. \\
\hline Salinity & $\mathrm{mg} \mathrm{L}^{-1}$ & 16900 & N.D. \\
\hline Aluminium* & $\mathrm{mg} \mathrm{L}^{-1}$ & 7625 & N.D. \\
\hline Ammonium** & $\mathrm{mg} \mathrm{L}^{-1}$ & 595.27 & 20.0 \\
\hline Cadmium* & $\mathrm{mg} \mathrm{L}^{-1}$ & 0.025 & 0.2 \\
\hline Calcium ${ }^{* *}$ & $\mathrm{mg} \mathrm{L}^{-1}$ & 95.38 & N.D. \\
\hline Lead $^{*}$ & $\mathrm{mg} \mathrm{L}^{-1}$ & 0.37 & 0.5 \\
\hline Chloride $^{* *}$ & $\mathrm{mg} \mathrm{L}^{-1}$ & 857.50 & 250 \\
\hline Copper* & $\mathrm{mg} \mathrm{L}^{-1}$ & 0.17 & 1.0 \\
\hline Iron* & $\mathrm{mg} \mathrm{L}^{-1}$ & 13.66 & 15.0 \\
\hline Lithium ${ }^{* *}$ & $\mathrm{mg} \mathrm{L}^{-1}$ & 15.22 & 2.5 \\
\hline Magnesium** & $\mathrm{mg} \mathrm{L}^{-1}$ & 15.37 & N.D. \\
\hline Manganese* & $\mathrm{mg} \mathrm{L}^{-1}$ & 0.31 & 1.0 \\
\hline Niquel$^{*}$ & $\mathrm{mg} \mathrm{L}^{-1}$ & 0.48 & 2.0 \\
\hline Nitrate* $^{* *}$ & $\mathrm{mg} \mathrm{L}^{-1}$ & 496.75 & 10 \\
\hline Potassium** & $\mathrm{mg} \mathrm{L}^{-1}$ & 694.46 & N.D. \\
\hline Sodium $* *$ & $\mathrm{mg} \mathrm{L}^{-1}$ & $1,172.46$ & N.D. \\
\hline Sulfate** & $\mathrm{mg} \mathrm{L}^{-1}$ & 846.00 & 250 \\
\hline Zinc ${ }^{*}$ & $\mathrm{mg} \mathrm{L}^{-1}$ & 1.13 & 5.0 \\
\hline
\end{tabular}

The analyzes carried out in the soil (Table 2) for the indirect impact test show that it has physical and chemical characteristics that guarantee an adequate environment for the development of the study. The values of $\mathrm{pH}$ and $\mathrm{Al}^{3+}$, which are the major limiting factors in the germination and development of the species in the initial period, presented results that are considered excellent since the limits would be $\mathrm{pH}$ lower than 7.0 and the concentration of $\mathrm{Al}^{3+}$ higher or equal to 0.03 . 
Table 2: Physico-chemical characteristics of soil.

\begin{tabular}{|c|c|c|c|c|c|c|c|c|c|c|c|}
\hline $\mathrm{pH}$ & $\mathrm{Ca}^{2+}$ & $\mathrm{Mg}^{2+}$ & $\overline{\mathrm{K}^{+}}$ & $\mathrm{Na}^{+}$ & $S$ & $\mathrm{Al}^{3+}$ & $\mathrm{H}^{+}+\mathrm{Al}^{3+}$ & $T$ & $\mathbf{P}$ & $\mathbf{V}$ & C.org. \\
\hline $\mathrm{H}_{2} \mathrm{O}$ & & - & - & $--\mathrm{cm}$ & $1_{c} \mathrm{dm}$ & & & - & $--\mathrm{mg} \mathrm{dm}^{-3}-$ & $----0 \%$ & \\
\hline 7.50 & 5.80 & 0.64 & 0.05 & 0.03 & 6.52 & 0.00 & 1.16 & 7.68 & 320.79 & 84.96 & 0.95 \\
\hline
\end{tabular}

$\mathrm{S}$ - sum of bases $(\mathrm{S}=\mathrm{Ca}+\mathrm{Mg}+\mathrm{Na}+\mathrm{K}+\mathrm{Al}) ;\left(\mathrm{H}^{+}+\mathrm{Al}^{3+}\right)-$ potential acidity; $\mathrm{T}-$ Value $\mathrm{T}(\mathrm{T}=\mathrm{S}+(\mathrm{H}+\mathrm{Al})) ; \mathrm{V} \%$ - base saturation $(\mathrm{V}(\%)=(\mathrm{S} \times 100) / \mathrm{T}) ; \mathrm{C}=$ organic carbon.

The mean values of the percentage of germination as a function of the different doses of landfill leachate are shown in Figure 1. Significant differences between treatments were observed by Tukey's test $(p<0.05)$. There was a decrease in the percentage of germination, when the dosage of the pollutant was increased. The treatments $\mathrm{T} 2$ and $\mathrm{T} 3 \mathrm{had}$ a germination rate of less than $80 \%$.

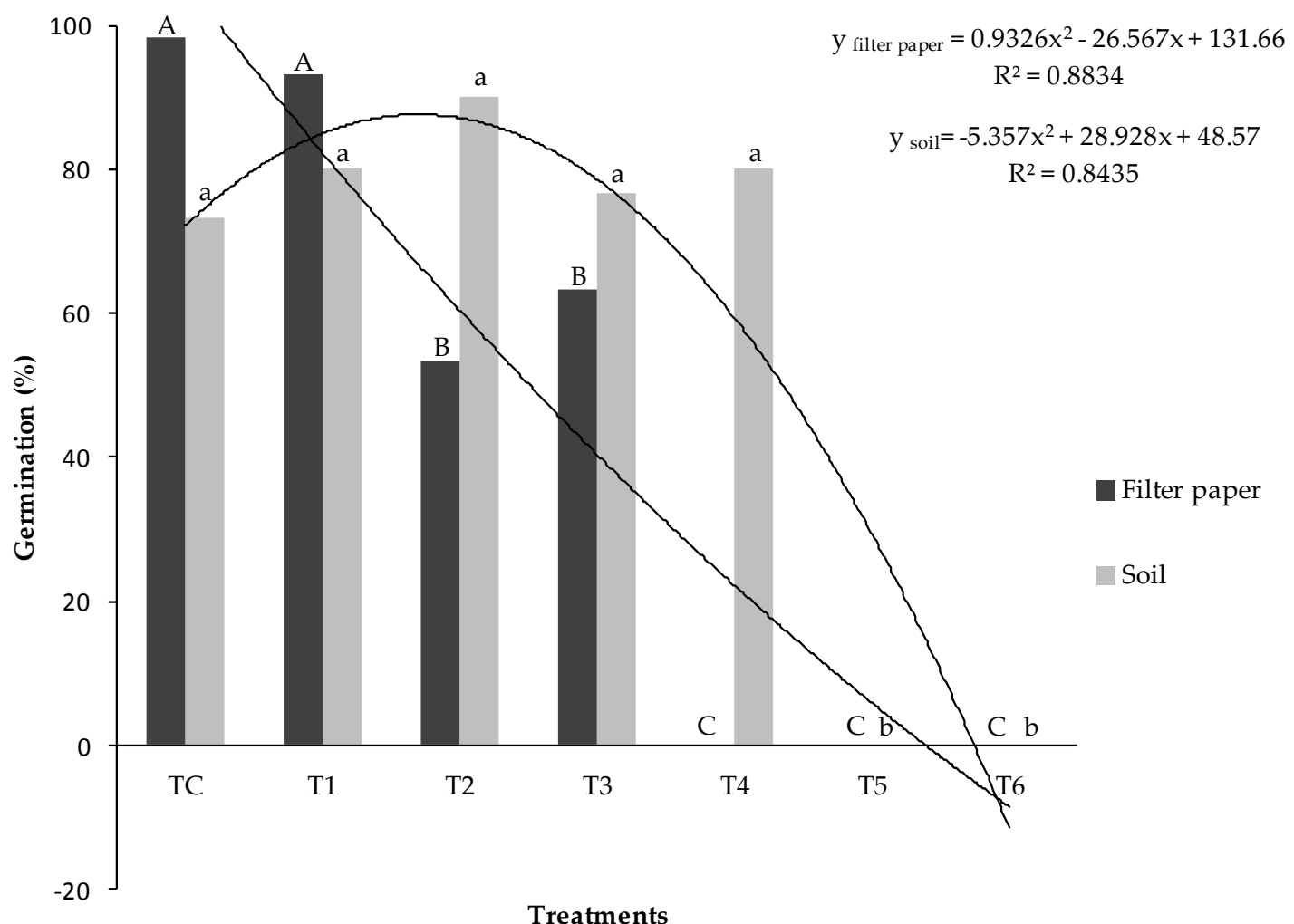

Figure 1: Average germination percentage $(\mathrm{G} \%)$ of lettuce submitted to the application of different doses of landfill leachate in two substrates, filter paper and soil.M (eans followed by the same capital letter and the same lowercase letter do not differ by the Tukey test at $5 \%$ probability. TC = deionized water control; T1 = leachate dose of $3.125 \%$; T2 = leachate dose of $6.25 \%$; T3 = leachate dose: $12.5 \%$; T4 = leachate dose of $25 \%$; T5 = leachate dose of $50 \%$; and T6 = leachate dose of $100 \%$ ).

Comparing the germination process on filter paper and soil (Figure 1), it can be verified that the limiting dosage for paper germination was obtained in the $12.5 \%$ (T3) treatment. After this dosage, it is observed a drastic reduction, leading to a total inhibition for the other treatments. Moreover, soil germination undergoes significant change only from the $25 \%$ treatment (T4). Thus, 
it is inferred that synergistic effects, as well as distribution of the pollutant along the soil mass, minimize the impact on germination of lettuce (Lactuca sativa L.) seeds.

Germination consists in the resumption of embryo growth (FRANCO, 2016). Even if the germination pattern and root growth are genetically programmed, its expression is modified by the environmental conditions to which the seeds are exposed, and the presence of a potentially toxic substance becomes determinant (SANTOS et al., 1992). High salinity impedes the absorption of water and, at the same time, facilitates the entry of toxic ions into the embedded seeds (AYERS and WESTCOT, 1999).

Santos et al. (2016) state that salinity-tolerant plants exhibit selective ion absorption so these plants have the ability to remove essential nutrients from the saline solution, where the concentration of non-essential ions is greater to regulate osmotic stress.

The germination test allows to infer the lethal toxic effect. However, it is necessary also the determination of doses that cause sublethal effects, for this, the length of the radicle from the germinated seeds is measured (RONCO et al., 2004). The mean values of lettuce root length as a function of the different doses of landfill leachate are shown in Figure 2. Significant differences between treatments were observed by Tukey's test $(\mathrm{p}<0.05)$.

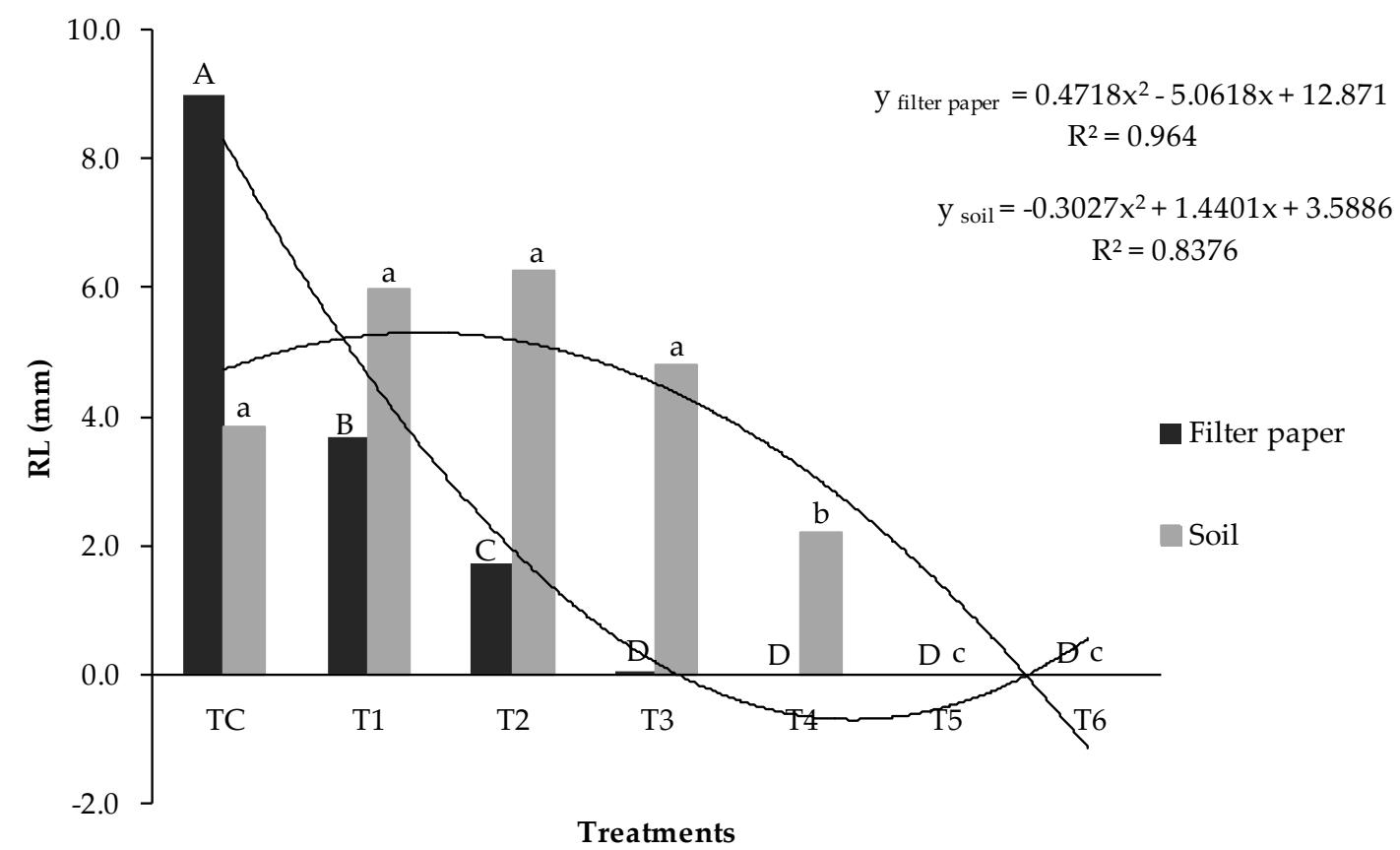

Figure 2. Average of radicle length (RL) of lettuce submitted to the application of different doses of landfill leachate in two substrates, filter paper and soil.M (eans followed by the same capital letter and the same lowercase letter do not differ by the Tukey test at $5 \%$ probability. TC $=$ deionized water control; $\mathrm{T} 1=$ leachate dose of $3.125 \%$; $\mathrm{T} 2=$ leachate dose of $6.25 \%$; $\mathrm{T} 3=$ leachate dose: $12.5 \%$; $\mathrm{T} 4=$ leachate dose of $25 \%$; $\mathrm{T} 5=$ leachate dose of $50 \%$; and $\mathrm{T} 6=$ leachate dose of $100 \%$ ).

The effect of the pollutant on the substrate filter papershowed the presence of the leachate even at low dosage causes a deleterious effect on the root length. The treatments $3.125 \%$ (T1) and $6.25 \%$ (T2), compared to the control group (CT) showed inhibition of radicle growth of approximately $59 \%$ and $81 \%$, respectively. It was not possible to identify the dose corresponding to NOEC because the lower dose (T1) was able to promote subtly perceptible effects, inhibiting 
the development of the radicle and hypocotyl length. The determination of the LOEC was established in the T1 treatment with $3.125 \%$ of the leachate.

In relation to root length results in soil, a significant effect was observed for the treatment with $25 \%$ (T4). The NOEC value was established in the treatment $12.5 \%$ (T3) and the LOEC value was obtained in the $25 \%$ treatment (T4). On average, the treatment caused approximately $58 \%$ reduction in radicle length. The similar behavior occurred in the germination with significant effect obtained in the treatment with $25 \%$ is emphasized.

Growth inhibition was also observed for the hypocotyl as the dosage of the pollutant was increased. The mean values of the lettuce hypocotyl length (Lactuca sativa L.) as a function of the different doses of landfill leachate are shown in Figure 3. Significant differences between treatments were observed by the Tukey's test $(p<0.05)$.

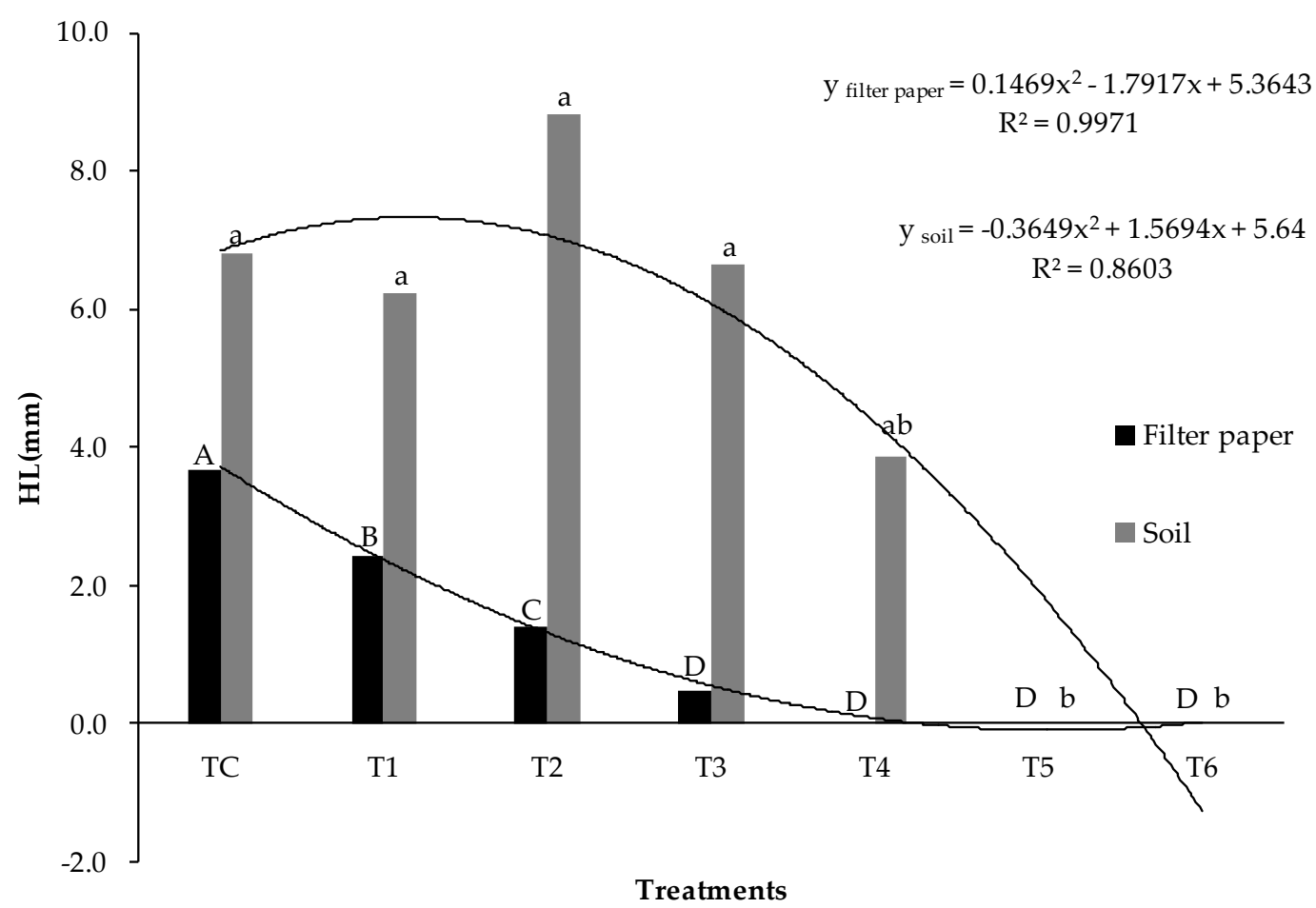

Figure 3. Average of hypocotyl length (HL) of lettuce submitted to the application of different doses of landfill leachate in two substrates, filter paper and soil.M (eans followed by the same capital letter and the same lowercase letter do not differ by the Tukey test at $5 \%$ probability. TC $=$ deionized water control; T1 $=$ leachate dose of $3.125 \%$; $\mathrm{T} 2=$ leachate dose of $6.25 \%$; $\mathrm{T} 3=$ leachate dose: $12.5 \%$; $\mathrm{T} 4=$ leachate dose of $25 \%$; $\mathrm{T} 5=$ leachate dose of $50 \%$; and $\mathrm{T} 6=$ leachate dose of $100 \%$ ).

$\mathrm{T} 1$ treatment showed inhibition of $34 \%$, T2 of $62 \%$ and $\mathrm{T} 3$ of $88 \%$, respectively. It was verified that the sublethal effect in the structures (radicle and hypocotyl) were obtained with the dose of $3.125 \%$ (T1). In this way, an extremely pronounced indirect impact is confirmed. However, germination showed inhibitory behavior from the dose with $12.5 \%$ (T3).

For the soil test, significant changes in hypocotyl length occured at doses greater than $25 \%$ corroborating with LOEC results obtained at radicle length for said medium.

The results of radicle and hypocotyl length corroborate with the perception of Ferreira and Aquila (2000). They affirm that the tests of first count, germination are less sensitive to the effects 
of chemical substances than the growth of the seedling. However, the experimental quantification is much simpler, because for each seed the phenomenon is discreet, germinates or does not germinate.

It can be assumed that the adverse effect observed in the present work is due to high salinity of the pollutant which acts to make water absorption difficult. Adittionally, the presence of other elements can configure levels that cause seed toxicity.

\section{Conclusions}

Toxicity tests using lettuce seeds proved to be an excellent methodology to verify the impact of land fill leachate, being low cost, easy and fast to execute with high sensitivity.

The physiological behavior of the lettuce presented different relations from the introduction of the pollutant, but mainly in relation to the substrate used for germination.

In both trials it was not possible to determine the LC50 from the doses tested, although it is observed that the filter paper test was more restrictive, since the $12.5 \%$ treatment was presented as a limit dose where germination inhibition occurs. It was observed that the sublethal effects (LOEC) for the pollutant, occur in the dose $3.125 \%$.

However, for the germination test in soil the results are more flexible in relation to the introduction of the pollutant, in that the value of LOEC, is obtained with the treatment corresponding to the $25 \%$ dilution, which also defines the maximum dosage in which it is not observed significant change in seed germination.

\section{References}

ACHEN, Christopher H. Measuring Representation: Perils of the Correlation Coefficient. American Journal of Political Science. 1977; 21 (4): 805-815.

ADAMS, W.J.; ROWLAND, C.D. Aquatic toxicology Test Methods. In HOFFMAN, D.J; RATTNER, B.A.; BURTON Jr, G.A.; CAIRNS Jr, J. (Editores) Handbook of Ecotoxicology, Washington, D.C.: Lewis Publishers. 2.ed. p. $32-58,2002$.

ALDRICH, J. H. Correlations Genuine and Spurious in Pearson and Yule. Statistical Science. 1995; 10 (4): 364-376.

ALMEIDA, C.; FERREIRA, D.; SECO, F.; IRIA, I. e JESUS, J. Análise Ecotoxicológica de Águas Residuais de Uma Indústria Metalúrgica. XI CNEA - Congresso Nacional de Engenharia do Ambiente. Lisboa, 2011.

APHA. AMERICAN PUBLIC HEALTH ASSOCIATION. Standard methods for examination of water and wastewater. Washington: American Water Works Association, 21th ed. 1.368 p. 2005.

ARAGÃO, M. A.; ARAÚJO, R. P. A. Métodos de ensaios de toxicidade com organismos aquáticos. In ZAGATTO, P.A.; BERTOLETTI, E. (Editores). Ecotoxicologia Aquática: Princípios e Aplicações, São Carlos, São Paulo: RIMA, 2008. P. 117 - 147.

ASSOCIAÇÃO BRASILEIRA DE NORMAS TÉCNICAS - ABNT. NBR 9897: Planejamento de amostragem de efluentes líquidos e corpos receptores - Procedimento. NBR - 9897/87. Rio de Janeiro, 22p. 1987. 
AYERS, R. S.; WESTCOT, D. W. A qualidade da água na agricultura. Campina Grande, UFPB, 1999. 153p.

BARASSI, C., AYRAULT, G., CREUS, C., SUELDO, R., SOBRERO, M. Seed inoculation with Azospirillum mitigates $\mathrm{NaCl}$ effects on lettuce. Scientia Horticulturae. 109(1): 8 - 14. 2006.

BASSANI, M. A. Fatores psicológicos da percepção da qualidade ambiental. In: BASSANI, M. A; BOLLMANN, H. A; MAIA, N. B.; MARTOS, H. L.; BARRELA, W. (Ed.). Indicadores ambientais: conceitos e aplicações. São Paulo: EDUC/ COMPED/ INEP, p. 47-57, 2001.

BRASIL. Ministério da Agricultura, Pecuária e Abastecimento. Regras para análise de sementes / Ministério da Agricultura, Pecuária e Abastecimento. Secretaria de Defesa Agropecuária. Brasília : Mapa/ACS, 2009. 399 p.

CARITÁ, R.; MARIN-MORALES, M. A. Induction of chromosome aberrations in the Allium cepa test system caused by the exposure of seeds to industrial effluents contaminated with azo dyes. Chemosphere, Elmsford, v. 72, n. 5, p.722-725, 2008.

CARVALHO, A. L.; MATOS, A. T.; HAMAKAWA, P. J.; AZEVEDO, R. F. Produção de percolado por resíduos sólidos urbanos de diferentes idades, na presença de resíduos da construção civil e sob recirculação. Engenharia na Agricultura, v.14, n.2, p.131-138, 2006.

CONAMA - Conselho Nacional do Meio Ambiente. Resolução n: 430/2011, de 13/05/2011. Disponível em: http://www.mma.gov.br/port/conama/legiabre.cfm?codlegi=646. Acesso em 10 Jul. 2017.

COSTA, C. R.; OLIVI, P.; BOTTA, C. M.; ESPINDOLA. E. L. G. A toxicidade em ambientes aquáticos: discussão e métodos de avaliação. Quim Nova. 31 : 1820-1830, 2008.

EMBRAPA - EMPRESA BRASILEIRA DE PESQUISA AGROPECUÁRIA. Manual de métodos de análises de solos. Rio de Janeiro: Embrapa-CNPS. 1997. 212p

FERREIRA, A. G.; AQUILA, M. E. A. Alelopatia: uma área emergente da ecofisiologia. Revista Brasileira de Fisiologia Vegetal, Brasília, v. 12, p. 175-204, 2000. Edição especial.

FRANCO, H. A. Introdução à Fruticultura. 1. ed. Curitiba: Livro Técnico, 180p. 2016. ISBN: 97885-8409-071-6.

INSTITUTO BRASILEIRO DE GEOGRAFIA E ESTATÍSTICA - IBGE. Pesquisa Nacional de Saneamento Básico. 2008.

KALCIKOVA, G.; ZAGORC-KONCAN, J.; GOTVAJN, A. Z. Evaluation of landfill leachate quality with battery of biotests. Acta Environmentalica Universitatis Comenianae (BRATISLAVA), Vol.19, Supplement, p. 145-150. 2011.

KURNIAWAN, T. A.; LO, W.; CHAN, G. SILLANPAA, M. E. T. Biological processes for treatment of landfill leachate. Journal of Environmental Monitoring, v. 12, p. 2032-2047, 2010. Disponível em:

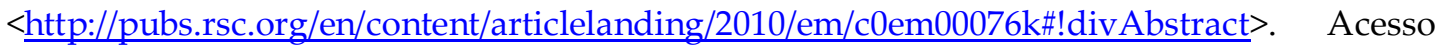
em: 14 abr. 2017.

LINDER, G.; GREENE, J.; RATSCH, H.; NWOSU, J.; SMITH, S. AND WILBORN, D. Seed germination and root elongation toxicity tests in hazardous waste site evaluation: Methods 
development and applications. U.S. Environmental Protection Agency, Washington, D.C., EPA/600/D-89/109 (NTIS PB90113184), 1989.

LOPES, P.R.M.; MONTAGNOLLI, R.N.; DOMINGUES, R.F.; BIDOIA, E.D. Toxicity and biodegradation in sandy soil contaminated by lubricant oils. Bull. Environ. Contam.Toxicol. 84 (4), 454-458. 2010.

OECD - Organization for Economic Cooperation and Development, 2003 - Terrestrial Plant Test: 208: Seedling Emergence and Seedling Growth Test. Guideline for the Testing of Chemicals Proposal for Updating Guideline 208.

RONCO, A.; BÁEZ, M. C. D.; GRANADOS, Y. P. Em Ensayos Toxicológicos y Métodos de Evaluación de Calidad de Aguas - Estandarización, Intercalibración, Resultados y Aplicaciones; Morales, G. C., ed.; Centro Internacional de Investigaciones para el Desarrollo: Ottawa, 2004, cap. 1.

SALEM, Y., HAMOURI, K., DJEMAA, R., ALOIS, K. Evaluation of landfill leachate pollution and treatment. Desalination 220, 108-114, 2008.

SANTOS, J. B.; GHEYI, H. R.; LIMA, G.S.; XAVIER, D.A.; CAVALCANTE, L.F.; CENTENO, C.R. M. Morfofisiologia e produção do algodoeiro herbáceo irrigado com águas salinas e adubado com nitrogênio. Comunicata Scientiae, v.7, n.1, p.86-96, 2016.

SANTOS, V.L.M.; CALIL, A.C.; RUIZ, H.A.; ALVARENGA, E.M.; SANTOS, C.M. Efeito do estresse salino e hídrico na germinação e vigor de sementes de soja. Revista Brasileira de Sementes, Pelotas, v. 14, n.2, p.189-194, 1992.

SILVA, F. de A. S.; AZEVEDO, C. A. V. de. The Assistat Software Version 7.7 and its use in the analysis of experimental data. Afr. J. Agric. Res, v.11, n.39, p.3733-3740, 2016. DOI: 10.5897/AJAR2016.11522.

SOBRERO, M. C.; RONCO, A. Ensayo de toxicidad aguda con semillas de lechuga (Lactuca sativa L.). In: Morales, G. C. Ensayos toxicológicos y métodos de evaluación de calidad de águas: Estandarización, Intercalibración, resultados e ya aplicaciones, IMTA, p. 63-72, 2004.

USEPA - United States Environmental Protection Agency - Seed Germination / Root Elongation Toxicity Tests. Ecological Effects, Tests Guidelines, 1996.

USEPA - United States Environmental Protection Agency. SW-846 EPA Method 3051A. Microwave assisted acid digestion of sediments, sludges, soils and oils. Test Methods for Evaluating Solid Waste. 3rd Update. Washington, DC, 1998. 